\title{
Economic Analysis of The Determinants Of Foreign Direct Investment (FDI) In Nigeria
}

\author{
Emmanuel Oluwagbenga Adebayo \\ Modibbo Adama University of Technology, \\ Yola - Nigeria \\ Suleiman Purokayo Gambiyo \\ Modibbo Adama University of Technology, \\ Yola - Nigeria.
}

\begin{abstract}
The study examined the factors that determine Foreign Direct Investment (FDI) in Nigeria. It assessed the extent to which exchange rate, interest rate, degree of trade openness affects foreign direct investment inflow to Nigeria. The study used data from Central Bank of Nigeria (CBN) Bulletin and World Bank (1981 - 2017). The results were interpreted based on the Ordinary Least Square (OLS) method, apart from series of test statistics and some diagnostics on data was performed. The estimated linear regression model reveals that the degree of openness positively and significantly affect FDI. Exchange rate has a positive but non-significant relationship with FDI and interest rate has a negative relationship with FDI, but it is not statistically significant. The study therefore recommends that economic policies that allow free trade should be formulated since macroeconomic policies are important in stabilization, enhance standard growth and improvements in the standard of living as a result of improved and higher productivity.
\end{abstract}

Keywords: FDI, Interest Rate, Trade Openness, Exchange Rate, Stabilization Policy.

\section{Background of the Study}

\section{INTRODUCTION}

Foreign Direct Investment (FDI) is a process whereby an investor resident in one economy has control or influence in the management of an enterprise that is resident in another economy by owning at least 10 percent of the ordinary shares of voting stock. It is an important aspect of International Finance. Foreign Direct Investment can be seen as a mechanism for promoting sustainable development in developing countries including Nigeria. Therefore, it is imperative that a conducive and enabling environment be created to attract investors and promote this concept. According to Suzana (2008), FDI is a key factor of economic development and a basic device for capital flows, which is superior to bank debts or portfolio equity investment

There are numerous benefits of FDI which include employment creation, transfer of technology, transfer of management experience, income generation, growth in GDP and advancement of international trade integration. Though exports do contribute to foreign resources, the trend has shifted to global finance via FDI, which is the prominent source as it is instrumental in creating assets in an economy. Sivapalan et al. (2014) stated that various foreign advisors and international organizations suggested that developing countries should focus on FDI as the primary source of external finance.

The main objective of this research is to analyze the determinants of FDI in the Nigerian economy. 
Despite the fact that Nigeria is endowed with abundant resources, the level of production and output is relatively low. Furthermore, the global prices of oil have been falling. Offiong and Atsu (2014) asserted that with the reduction in oil prices, it became clear that along with official development assistance, alternative sources of development financing must be sought.

It is widely recognized that FDI produces economic benefits to the recipient countries by providing capital, foreign exchange, technology, competition and by enhancing access to foreign markets. It is also argued that FDI can enhance domestic investment and innovation (Mottalleb, 2007).

FDI has been considered as a mechanism for increasing the level of production and output as it complements domestic investment. Hence, to attract FDI inflows to any economy, the investment climate must be conducive for investment.

\section{Theoretical Literature}

\section{LITERATURE}

Theories reviewed are relevant in explaining the workings of Foreign Direct Investment. Some of these are:

\section{The Neo-Classical Theory of Economic Growth}

According to this theory, all development is dependent on the use of land, labour, and capital. Since labour and land have been underutilized in least developed countries, low savings rate, productivity of capital is likely to be greater here. The theory presumes that developing countries benefitted more than the developed countries, from the interdependence between countries. This is based on the assumption that capital normally flows from rich to poor areas where the returns on capital investment will be highest, which will eventually lead to the transformation of backward economies (Offiong \& Atsu, 2014).

\section{The two gap model (The Investment Theory)}

This theory is as a result of the Harrow-Domar's growth model which posits that the developing economies face two gaps in their economy which they have to fill. These are the gap between savings and investment and the gap between exports and imports. This theory suggests that developing countries deficient in savings should outsource investment to ensure economic growth (Offiong \& Atsu, 2014).

\section{Empirical Review}

FDI has played a very critical role in industrial and economic development of countries over the years. This has given rise to various empirical studies. Some of these studies focused on the role played by FDI in the process of economic growth while others focused on the determinants of FDI. These studies are reviewed below:

Dunning (1973) as cited by Louis (1998) classified the determinants of FDI into three:

(i). Market factors such as size and growth of the market measured by the GNP of the recipient country.

(ii). Cost factors such as the availability of labour, low labour costs and inflation and

(iii). The investment climate as measured by the degree of foreign indebtedness and the state of the balance of payments.

Louis (1998) analyzed the determinant of FDI in Nigeria and observed that FDI is affected by the real growth and lending rates, the inflation rate and level of public investment.

Wafure and Nurudeen (2010) asserted that political instability had a positive effect on FDI. They used the error correction technique to analyze the relationship between FDI and its 
determinants. The results revealed that the main determinants of FDI are market size, deregulation, political instability, and exchange rate depreciation.

Ebiringa and Emeh (2013) observed that exchange rate, GDP, inflation, stock market capitalization and interest rate individually and jointly affect FDI inflows. They also discovered a negative relationship between exchange rate and FDI. Their recommendation was that concerted efforts must be made to strengthen the capacity of economic planning and management institutions in order to ensure stability in macroeconomic performance which provides an enabling environment for FDI inflows.

Effiong and Ignatius (2014) used regression analysis and observed that improvement in the GDP and increase in wage rate has positive impact on the FDI inflow.

Akpan, Isihak and Asongu (2014) analysed the determinants of FDI in 9 countries (Brazil, Russia, India, China and South Africa, Mexico, Indonesia, Nigeria and Turkey) for the period between 2001 and 2011, using panel data. The results indicate that trade openness is one of the determinants of FDI inflow in those countries.

Adelowokan, Adesoye and Buraimos (2014) investigated the determinants and effects of FDI on the Nigerian economy using multiple regression analysis. They found that a strong exportation of goods and services as well as investment in Nigeria promoted FDI. Moreover, export, favorable exchange rate, and investment enhanced the economic growth of the country. Mohammed and Samwel (2015) analysed the determinants of FDI in Kenya and found out that exchange rate and real GDP significantly and positive affect FDI.

Cornelius, Arikpo and Ogar (2015) observed that while trade openness had strong relation with FDI, market capitalization, gross fixed capital formation, and level of economic activities had weak relation with FDI.

Owolabi and Ayenakin (2015) used the OLS technique and observed that there is a negative relationship between FDI and insecurity. They recommended that strong policy stance must be taken on the issue of insecurity in Nigeria so as to attract more FDI.

Ndugbu, Duruechi and Ojegbe (2017) used Vector Auto Regression (VAR) analysis and observed that Interest Rate, Inflation Rate and RGDP (economic growth) put together have significant positive impact on FDI in Nigeria, while Mohammed and Samuel (2015) asserted that exchange rate is significantly positively correlated with the level of foreign direct investment.

Kalu, Nkwor, Obasikene and Nwonye (2016) used OLS technique to examine the relationship between independent variables such as trade openness, real exchange rate, financial market development and the dependent variable, FDI in Nigeria. The result indicated that FDI was a positive and significant function of trade openness. Real exchange exchange rate had a positive but non-significant relationship with FDI.

\section{Type and Source of Data Used}

\section{METHODOLOGY}

Secondary data on FDI, Rate of Growth of GDP, Interest Rate, Exchange Rate, and Inflation Rate from the period of 1980 to 2017 were sourced from the Central Bank of Nigeria Bulletin of various editions. 


\section{Method of Data Analysis}

An econometric equation was formulated on the basis of which the relationship between the variables (dependent and independent) was determined. The regression of the independent variables of exchange rate, inflation rate, interest rate and real GDP on the dependent variable of FDI were estimated using the OLS method due to its BLUE (Best, Linear, Unbiased, Estimate) property.

Moreover, trend analysis was used to assess the trend of the macroeconomic variables and FDI. E-views statistical package and Microsoft Excel were used for the analysis.

\section{Trend Analysis}

\section{RESULTS AND DISCUSSION}

The trend analysis shows that FDI has been increasing from 1981 to 2017. This can be seen in Figure 1.

Figure 1: Trend Analysis

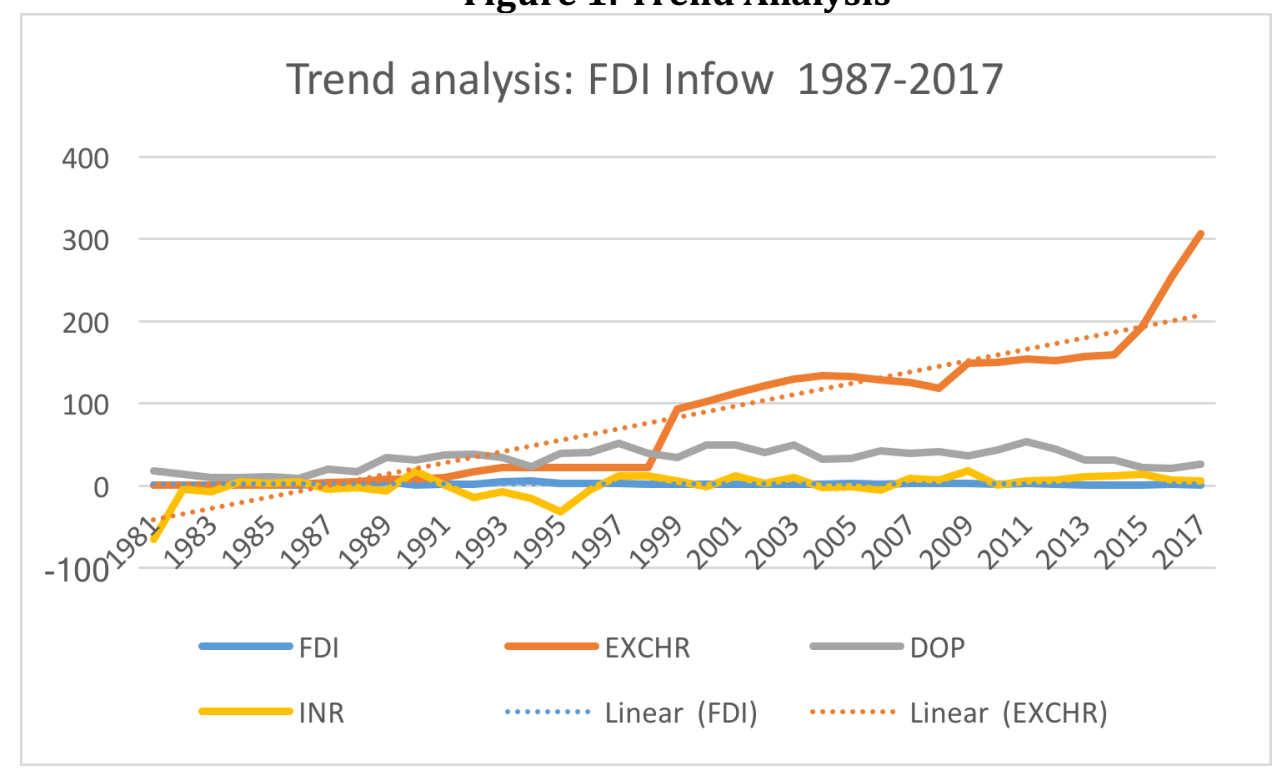

Source: Survey (2019)

\section{Data Processing and Pre-Estimation Diagnostic}

The data used in this study was log-transformed in order to improve the linearity of variables and improve its interpretability and consequently, the analysis.

\section{Test for Stationarity}

Results of Applying Augmented Dickey Fuller Test on Study Variables. The Augmented DickeyFuller (ADF) unit root test was conducted to examine whether the variables are stationary or not. The null hypothesis is that of non-stationarity while the alternative hypothesis is that of stationarity. If the t-statistic is compared with the p-value. If the p-value is less than the critical value of $\alpha=0.05$, we reject the null hypothesis of non-stationarity and therefore, the series is stationary. On the other hand, if the p-value is more than the critical value of $\alpha=0.05$, we fail to reject the null hypothesis of non-stationarity and the series is therefore non-stationary and may lead to a spurious regression.

The results showed that all the variables were stationary at first difference as seen in Table 4.1 
Table 2: Result of Unit Root Test

\begin{tabular}{|l|c|c|c|c|c|}
\hline Variables & \multicolumn{2}{|c|}{ ADF test at level } & \multicolumn{2}{c|}{ ADF test at first difference } & Order of integration \\
\hline & T-value & P-value & T-value & P-value & I (1) \\
\hline LFDI & -2.552107 & 0.3030 & -10.97005 & 0.0000 & I (1) \\
\hline LEXCHR & -1.340078 & 0.8613 & -5.411918 & 0.0005 & I (1) \\
\hline LINR & -7.288627 & 0.0000 & -9.291786 & 0.0000 & I (1) \\
\hline LDOP & -1.800922 & 0.6834 & -7.410279 & 0.0000 & I (1) \\
\hline
\end{tabular}

Source: Statistical analysis

\section{Co-integration Test}

Table 3: Result of Co-integration Test

\begin{tabular}{|l|c|c|c|c|}
\hline \multirow{2}{*}{ Null Hypothesis } & \multicolumn{2}{|c|}{ Test Statistics } & \multicolumn{2}{c|}{ Critical Values (5\%) } \\
\cline { 2 - 5 } & Trace & Max Eigen & Trace & Max Eigen \\
\hline None* & 66.14624 & 38.29970 & 47.85613 & 27.58434 \\
\hline At most 1 & 27.84654 & 12.67330 & 29.79707 & 21.13162 \\
\hline At most 2 & 15.17325 & 7.785475 & 15.49471 & 14.26460 \\
\hline At most 3* & 7.387772 & 7.387772 & 3.841466 & 3.841466 \\
\hline
\end{tabular}

\section{The Breusch-Godfrey Correlation LM Test}

When using the Dubin Watson test, you may only test the null hypothesis of no serial correlation against the alternative hypothesis of first-order serial correlation. The BreuschGodfrey Correlation LM test overcomes these limitations.

The p-value is 0.0874 which is higher than 0.05 which means we fail to reject the null hypothesis of no serial autocorrelation. Therefore, there is no serial correlation in the model. This can be seen in Table 4.3 below

Table 4: Results of the Breusch-Godfrey Serial Correlation LM Test Breusch-Godfrey Serial Correlation LM Test:

\begin{tabular}{llll}
\hline \hline F-statistic & 2.639307 & Prob. F(2,31) & 0.0874 \\
Obs*R-squared & 5.383578 & Prob. Chi-Square(2) & 0.0678 \\
\hline \hline
\end{tabular}

\section{The Breusch Pagan Godfrey Test}

Testing for heteroskedasticity, the result of the Breusch Pagan Godfrey Test indicates a $\mathrm{p}$ value of 0.1160 which means we fail to reject the null hypothesis of no heteroskedasticity. Therefore, there is no heteroskedasticity in the model. This can be seen in Table 5 below:

Table 5: Heteroskedasticity Test: Breusch-Pagan-Godfrey

\begin{tabular}{llll}
\hline \hline F-statistic & 2.123763 & Prob. F(3,33) & 0.1160 \\
Obs*R-squared & 5.987553 & Prob. Chi-Square(3) & 0.1122 \\
Scaled explained SS & 9.837164 & Prob. Chi-Square(3) & 0.0200 \\
\hline \hline
\end{tabular}




\section{Result of the Regression Analysis}

Table 6: Regression Result

Dependent Variable: @LOG(FDI)

Method: Least Squares

Date: 09/20/19 Time: 02:14

Sample: 19812017

Included observations: 37

\begin{tabular}{lrlll}
\hline \hline \multicolumn{1}{c}{ Variable } & Coefficient & Std. Error & t-Statistic & Prob. \\
\hline \hline C & -3.657861 & 0.719328 & -5.085106 & 0.0000 \\
@LOG(EXCHR) & 0.000121 & 0.073812 & 0.001634 & 0.9987 \\
$\quad$ INR & -0.001797 & 0.006743 & -0.266585 & 0.7914 \\
@LOG(DOP) & 1.183213 & 0.259990 & 4.550989 & 0.0001 \\
\hline \hline R-squared & 0.582067 & Mean dependent var & 0.328875 \\
Adjusted R-squared & 0.544073 & S.D. dependent var & 0.779032 \\
S.E. of regression & 0.526021 & Akaike info criterion & 1.654854 \\
Sum squared resid & 9.131035 & Schwarz criterion & 1.829008 \\
Log likelihood & -26.61481 & Hannan-Quinn criter. & 1.716252 \\
F-statistic & 15.32001 & Durbin-Watson stat & 1.187626 \\
Prob(F-statistic) & 0.000002 & & & \\
\hline \hline
\end{tabular}

The Adjusted R-Squared of 58\% is impressive. This implies that most of the variation in FDI is explained by the estimated model. Degree of Openness (DOP) was statistically significant at $5 \%$ level of significance, while the others were not statistically significant at the same level of confidence. The signs of the linear estimation were consistent with the theory.

In general, the estimated model is reliable in the following sense: measures of statistical reliability of parameter estimates (t-statistic), model (F-statistic), and the measure of goodness of fit (Adjusted R-Squared).

\section{Summary of the Findings}

This section includes a discussion of all the variables of the estimated model relating to sign, statistical significance, and the implication of the same.

\section{Exchange Rate}

Exchange Rate has a positive coefficient but it is not statistically significant at 5 percent level of significance. The positive coefficient of Exchange Rate disagrees with the with findings of Masayuki and Ivohasina (2005) and that of Wafure and Nurudeen (2010) who asserted that 1 percent depreciation in exchange rate causes FDI to increase by approximately 0.02 . However, it is in line with the findings of Adewolaka et al. (2014) and that of Mohammed and Samwel (2015) who asserted that the levels of exchange rate affect FDI through the current account. They also stated that an increase in exchange rates makes the domestic currency to appreciate. Thus, FDI inflows will increase because external borrowing will be cheaper than domestic borrowing.

\section{Interest Rate}

Interest Rate has a negative coefficient which is in line with the a priori expectation. However, it is not statistically significant at 5 percent level of significance. 


\section{Trade openness}

Trade openness has a positive and significant relationship with FDI. This is in line with the results of Cornelius, et. al (2015) and Kalu, et. al (2016).

\section{CONCLUSION AND RECOMMENDATIONS}

This study sought to conduct an empirical investigation on the determinants of FDI in Nigeria. The theoretical framework is based on the neo-classical theory of economic growth and the two gap model (The investment theory).

The econometric tests used ensured that the regression analysis avoided problems of spurious regression which occur when variables are non-stationary. The estimated linear regression model revealed that trade openness is the most significant determinant of FDI inflows in Nigeria. Exchange rate has a positive but non-significant relationship with FDI. Interest rate has a negative but non-significant relationship with FDI. Fifty-eight percent (58\% Adjusted RSquared) of the variation is explained by the estimated model. Other variables that not captured in the model like terrorism, inflation rate and real gross domestic product (RGDP) can partly explain the remaining variation.

As pointed out earlier, FDI has an important role to play in the economy in terms of employment creation, transfer of technology, transfer of management experience, growth in GDP, income generation, advancement of international trade integration, etc.

From this premise, policy recommendation arose based on the findings from the study. Economic policies that allow free trade and investment should be implemented. This means little regulation, no control on currency exchange. Further-more, the governments should formulate and implement policies that encourage trade liberalization because the greater the openness of an economy, the greater the flow of FDI into that economy. There is therefore a strong recommendation for a greater measure of trade liberalization to drive FDI inflows into country.

\section{References}

Adewolakan, O.A., Adesoye, A. and Buraimo, 0. (2014). An appraisal of the determinants and effects of foreign direct investment on the Nigerian economy. Ago-Iwoye Journal of Social and Behavioural Sciences 3(2), 65-85.

Akpan, U. S., Isihak, S. R., \& Asongu, S. A. (2014). Determinants of foreign direct investment in fast-growing economies: a study of BRICS and MINT. African Governance and Development Institute WP/14/002.

Central Bank of Nigeria (2016). Statistical Bulletin.

Cornelius, M.O., Arikpo, O.F. and Ogar, A. (2015). Determinants of foreign direct investment inflow to Nigeria. IOSR Journal of Humanities and Social Science (IOSR-JHSS) 20(8), 34-43.

Dunning, J.H. (1981). Explaining the international direct investment position of countries: towards a dynamic or developmental approach. Weltwirtschaftliches Archiv 117, 30-64

Ebiringa, 0.T. and Emeh, Y. (2013). Determinants of foreign direct investment inflow: A focus on Nigeria. European Journal of Business and Management 5(24), 41-52.

Kalu, E.U., Nkor, N.N., Obasikene, A.C. \& Nwonye, N. (2016). Responsiveness of foreign direct investment to trade openness in Nigeria. Researchjournali's Journal of Economics, 4(5), 1-11.

Louis, N.C. (1998) Determinants of foreign direct investment in Nigeria: An error correction specification. The Journal of Economic and Social Studies 40(1), 1-17.

Masayuki, H. \& Ivohasina, F. (2005). The determinants of foreign direct investment into Japan. Kobe University Economic Review 51 
Mohammed, M.W. and Samwel, N.M. (2015). Analysis of the determinants of foreign direct investment in Kenya. Journal of Multidisciplinary Scientific Research. 3(4), 16-26.

Mottaleb K.A.C (2007). Determinants of foreign direct investment and its impact on economic growth in developing countries. http://mpra.ub

Ndugbu, M.O., Duruechi, A.H. and Ojegbe, J.S. (2017). Macroeconomic policy variables and foreign direct investment in Nigeria. IIARD International Journal of Banking And Finance Research 3(2), 112-136.

Offiong, A.I. and Atsu, I.A. (2014). Determinants of foreign direct investment in Nigeria (1980-2011). International Review of Management and Business Research 3(3), 1538-1549.

Owolabi, A and Ayenakin, O.O. (2015). Insecurity and foreign direct investment in Nigeria. International Journal of Sustainable Development and World Policy. 4(4), 56-68.

Suzana, S. (2008). Analytical Framework of FDI Determinants: Implementation of the OLI model. Facta Universitatis Series: Economics and Organization. 5(3), 239-249.

Thrunavukkarasu, V., Sivapalan, A. and Rajedran, K. (2015). Foreign direct investment and economic Growth: Evidence from Sri-Lanka. International Journal of Business and Management 9(1), 140-148.

Wafure, O. G \& Nurudeen, A. (2010). Determinants of foreign direct investment in Nigeria: An empirical analysis. Global Journal of Human Social Science 10(1), 26-34. 